\begin{tabular}{lllll} 
Volumen 35(2):5-13 & (cc) EY-NC & ISSN Impreso 0120-0135 & e-ISSN 2256-2273 & doi: http://dx.doi.org/10.22267/rcia.183502.86 \\
\hline
\end{tabular}

\title{
In vitro arrow cane (Gynerium sagitatum Aubl.) multiplication in double phase medium
}

\author{
Multiplicación in vitro de caña flecha (Gynerium sagitatum Aubl.) \\ en medio doble fase
}

\section{Claudia López D. ${ }^{1}$; Isidro E. Suárez ${ }^{2}$}

1 Investigadora, Instituto de Biotecnología Aplicada para el Caribe (IBAC), Universidad de Córdoba, Montería, Colombia, clamalodi@gmail.com.

2 Docente, Ph.D. Instituto de Biotecnología Aplicada para el Caribe (IBAC), Universidad de Córdoba, Montería, Colombia, iesuarez@coreo.unicordoba.edu.co.

Citar: Lopez, C. \& Suarez, I. (2018). In vitro arrow cane (Gynerium sagitatum Aubl.) multiplication in double phase médium. Revista de Ciencias Agrícolas. 35(2): 5-13 doi:http://dx.doi.org/10.22267/ rcia.183502.86

Received: august $252017 . \quad$ Accepted: september 242018.

\begin{abstract}
Arrow cane (Gynerium sagitatum Aubl.) is a Poaceae species used as fiber source to make traditional and valuable handmade craftsmanship by indigenous communities in Northern Colombia. Since no commercial crops are established fiber needs are taken from natural plant populations affecting ecosystem. A micropropagation protocol to clonally multiply large quantities of arrow cane plant material for planting commercial crops has been developed; however, micropropagated plants are costly compared to naturally extracted plant material. To reduce micropropagated plants costs, in the present research a double phase medium formulation along with continuous shoot culture with no periodic transfers to fresh medium was compared to semisolid medium system with subculture every four weeks with respect to multiplication rate and costs of micropropagated plants. The results showed that continuous culture of explants with double phase medium and no periodic transfers resulted in higher multiplication rates and larger shoots compared to shoots cultured using the conventional semisolid medium system and transfer to fresh medium every four weeks. Plants from both, semisolid and double phase culture system, fully adapted and recovered when transferred to ex vitro conditions. The cost analysis showed that double phase cultured shoots are $\geq 20 \%$ less expensive.
\end{abstract}

Keywords: In vitro propagation, double phase, axillary meristems, BAP, ex vitro. 


\section{RESUMEN}

Caña flecha (Gynerium sagitatum Aubl.) es una especie de la familia Poaceae utilizada como fuente de fibra para elaborar tradicionales y valiosas artesanías por comunidades indígenas de la Costa Norte Colombiana. Debido a que no existen cultivos comerciales, la fibra para las necesidades de la industria son tomadas de plantaciones naturales afectando el ecosistema. Para proveer material vegetal para la siembra de cultivos comerciales, un protocolo para la multiplicación clonal masiva de plantas de caña flecha ha sido desarrollado; sin embargo, las plantas micropropagadas resultan costosas comparadas con los propágulos extraídos de las poblaciones naturales. Con el fin de reducir los costos de las plantas, en el presente estudio se evaluó el uso de medio doble fase y cultivo continuo de brotes sin transferencias periódicas a medio fresco comparado con el sistema convencional en medio semisólido con transferencias cada cuatro semanas a medio fresco, con respecto a la tasa de multiplicación y costos de las plantas micropropagadas. Los resultados mostraron que el cultivo en medio doble fase sin transferencias periódicas a medio fresco resultó en tasas de multiplicación más altas y brotes de mayor longitud al compararlos con los brotes obtenidos en medio semisólido y transferencias cada cuatro semanas. Tanto los brotes cultivados en medio doble fase como los cultivados en medio semisólido se adaptaron y establecieron normalmente cuando fueron trasplantados a condiciones ex vitro. El análisis de costos mostró que los brotes multiplicados en medio doble fase son $\geq 20 \%$ menos costosos y se recuperan ex vitro similar a los obtenidos mediante transferencias mensuales a medio fresco.

Palabras clave: Propagación in vitro, doble fase, meristemos axilares, BAP, ex vitro.

\section{INTRODUCTION}

Arrow cane (Gynerium sagitatum Aubl.) is a Poaceae species native to West India and distributed from México through Paraguay in the American continent. The plant is well adapted to inter tropical zone conditions with a better growth rate in wetlow lands, organic soils and altitude up to $1600 \mathrm{~m}$ above sea level (GRIN, 2013). Cultivation and processing of arrow cane have been the main income source for communities of the Zenú Indian group, most of them dedicated to make craftsmanship products from the plant's central nerve becoming the most famous handmade Colombian products (DANE, 2005). Recent studies evidenced the potential for landfill phytoremediation using arrow cane alone or in association with other plant species (MaderaParra, 2015a, 2015b).
Arrow cane propagates by sexual and clonal methods; plants are dioceaus and flowers can be wind pollinated, seeds index is around 1.7 million $\mathrm{Kg}^{-1}$ and, when viable, seeds can germinate from three to seven days after imbibition at $20-30^{\circ} \mathrm{C}$. Flowering usually occurs at the stem terminal in 18-20 months old stem; however, under Humid Caribbean conditions sexual propagation does not occur because seeds are unviable. Clonal propagation is the current way for plant multiplication and dissemination; the new shoots emerge from underground rhizomes that expand radially up to $20 \mathrm{~m}$ from the main stem. The newly grown stems eventually mature and flower becoming a new source for basal growing shoots. This growth and propagation habit is not only very efficient for colonization new territories but also an effective way to preserve wetlands and shores from erosion and degradation (Kalliola et al.,1992; Araméndiz et al., 2005). 
Arrow cane plant extraction from wild populations to make craftsmanship (hats, rings, shoes, etc.), homes, musical instruments and ornamental products happens at a very high rate since commercially crops are not available. It is estimated that more than $50 \%$ of arrow cane natural populations in the Colombian Northern Coast have been eliminated in the past 10 years becoming a cultural, economic and environmental issue. Several studies have been conducted aimed at developing an efficient propagation method for natural restoration and commercial crops for fiber production (Araméndiz et al., 2005, Suarez et al., 2013).

Micropropagation is a clonal propagation technique that allows massive plant multiplication in short periods of time, reduced space and under aseptic conditions (Sinhg et al., 2013; Waikhom and Louis, 2014). Micropropagated plants are cultured from explants, established in closed containers with nutrient media and hormone supply that result in high levels of genetic and phenotypic uniformity. Usually, micropropagation requires fully equipped labs, relatively high amount of reagents, well trained people and many labor hours which results in high plant costs (Shinde et al., 2016). Several studies related to developing micropropagation strategies for arrow cane in order to produce massive plant material for planting commercial crops have been reported (Pastrana and Suarez, 2009, Suarez et al., 2009; Rivera et al., 2009; Suarez et al., 2017); however, micropropagated plants results in higher costs than planting material from natural populations. Double phase medium system have been implemented to reduce costs of Vitis vinifera (Couselo et al., 2006), Ananas comosus (Scherwinski-Pereira et al., 2012) and Whitania somnifera (Singh et al., 2016) micropropagated plants by means of reduced gelling agents, subculture, reagents and labor hours in the process. In the present research, double phase medium with continuous shoot growth in the same recipient was compared to conventional semisolid medium system for Gynerium sagitatum micropropagation with respect to multiplication rate and costs variables.

\section{MATERIALS AND METHODS}

Plant material. Plant material consisted of in vitro established arrow cane plants cultivar "Criolla" cultivated for 12 months with monthly subcultures. The culture medium was MS (Murashige and Skoog, 1962) supplied with (in $\mathrm{mg} \mathrm{L}^{-1}$ ) myo inositol (100), sucrose (30.000), thiamine $\mathrm{HCl}(0.4)$ and Phytage $\mathrm{l}^{\circledR}$ (3.000) (Sigma $\mathrm{Co}^{\circledR}$.). The explants consisted of clusters with three 3-4 cm long shoots obtained from established plants after four weeks of subculture. The cultures were stored at $25^{\circ} \mathrm{C}$ with $12 \mathrm{~h}$ photoperiod provided by cool white fluorescent tubes (40-50 $\mu \mathrm{mol} \mathrm{m} \mathrm{m}^{-2} \mathrm{~s}^{-2}$.

Shoot multiplication. Clusters with three stems were established into $750 \mathrm{~cm}^{3}$ polycarbonate flasks containing double phase medium consisting of $100 \mathrm{~cm}^{3}$ MS semisolid bottom medium added with $30 \mathrm{~cm}^{3}$ liquid MS medium on top of the semisolid phase; four explants were established in each container and the liquid phase was re-plenished every two weeks inside of a laminar flow hood to avoid contamination. For conventional semisolid system, similarly processed explants were cultivated in $30 \mathrm{~cm}^{3}$ MS semisolid medium contained in $125 \mathrm{~cm}^{3}$ polycarbonate flasks; a single explant was established in each container and total explants were transferred to fresh medium of the same formulation every four weeks.

The medium formulation for both treatments was MS (Murashige and Skoog, 1962) supplied with (in $\mathrm{mg} \mathrm{L}^{-1}$ ) mio inositol (100), sucrose (30.000), thiamine $\mathrm{HCl}$ (0.4) and BAP (0.5); the semisolid phase was added with Phytage ${ }^{\circledR}$ (3.000) (Sigma Co.). All flasks were covered with heavy duty aluminum foil and sealed with Nescofilm ${ }^{\circledR}$. The cultures were stored at $25^{\circ} \mathrm{C}$ with $12 \mathrm{~h}$ photoperiod provided by cool white fluorescent tubes (40-50 $\mu \mathrm{mol} \mathrm{m} \mathrm{m}^{-2}$ ) during 120 days. 
Treatments, consisting of double phase medium dispensed in $750 \mathrm{~cm}^{3}$ containers and semisolid medium dispensed in $250 \mathrm{~cm}^{3}$, each treatment was replicated 10 times for a total of 20 experimental units distributed with a complete randomized design. After 120 days in culture, the total number of shoots, shoots per flask, newly formed shoots per explant and shoot length were registered. Data were analyzed using $T$ test based on the $Y_{u}=\mu_{j}+\beta_{j}+\varepsilon_{j j w}$ here $\mu$ was the overall mean, $\beta$ was the effect of medium consistency and container and $\varepsilon$ was the experimental error. Costs of shoot production were quantified based on the multiplication rate and cost of elements used for each system.

Medium sterilization. The $\mathrm{pH}$ of all media was adjusted to 5.7-5.8 prior to addition of gelling agent when indicated. Media were sterilized by autoclaving at $120^{\circ} \mathrm{C}$ and $1.2 \mathrm{~kg} \mathrm{~cm}^{-2}$ for $15 \mathrm{~min}$.

Transfer to ex vitro conditions. Micropropagated shoots were washed with sterile distilled water to remove medium residues and transplanted into 72plug containers filled with peat as substrate. The containers were placed in a shade house with $20 \%$ light coverage with Saram ${ }^{\circledR}$ and irrigation provided by a fog system every 20 min for 30 seconds during the first two weeks. After two weeks, plants were transferred to $50 \%$ light coverage with Saram ${ }^{\circledR}$ and irrigated three times a day two minutes each. Seven weeks after transferring to ex vitro conditions, the number of plants that survived and adapted to normal conditions was recorded and survival rate calculated.

\section{RESULTS AND DISCUSSION}

New shoots formed from established explants were visible after two weeks in culture from both double phase and semisolid medium cultures. New shoots showed a healthy growth pattern with no phenol emission or contamination symptoms; no callus tissue or adventitious shoot growth was observed. This growth performance is typical of in vitro established cultures when transferred to BAP supplied medium. Cultures adapted to in vitro conditions respond accordingly to PGR supply in contrast non-in vitro adapted cultures usually show a non-synchronic growth with large asymmetric organs, phenol emission and necrotic tissues (Suárez et al., 2009; Pastrana and Suárez, 2009).

The results of the $T$ student test applied to the data allowed to detect statistical differences for total number of shoots ( $P r=0.0001)$, number of shoots per flask ( $P r=0.0011)$, mean number of newly formed shoots per explant (Pr=0.0148) and shoot length (Pr= 0.0001) as a result of the applied treatments (Table 1). The analysis showed that continuous culture of arrow cane explants in double phase medium significantly increases the total number of shoots, the number of new shoots per explant, the number of shoots in each individual flask and the length of shoots compared to the conventional semisolid medium system in the same time frame (90 days) (Table 1 , Figure 1).

The cost analysis of micropropagated shoots at a rate of 6.8 new shoots per explant using a conventional semisolid medium system with four week transfer to fresh medium estimates a cost of US\$0.18 per shoot (López, 2016). The results of the present research showed that multiplication rate in double phase medium can be about two folds (13) compared to semisolid medium system. Considering the medium quantity needed for each system, gelling agent amount, labor related to subculture and washing glassware; it is estimated that double phase medium system can lower the total cost of plants by $20 \%$ compared to semisolid medium cultures system (Table 1 ). 
Table 1. In vitro multiplication of Gynerium sagitatum Aubl. Shoots in double phase and semisolid medium after 120 days in culture.

\begin{tabular}{lccccc}
\hline Medium & $\begin{array}{c}\text { Total shoots } \\
\text { produced }\end{array}$ & $\begin{array}{c}\text { Shoots per } \\
\text { flask }\end{array}$ & $\begin{array}{c}\text { Shoots per } \\
\text { explant }\end{array}$ & $\begin{array}{c}\text { Shoot } \\
\text { length }(\mathbf{c m})\end{array}$ & $\begin{array}{c}\text { Shoot cost } \\
\text { (US\$) }\end{array}$ \\
\hline Double phase & $855 \mathrm{~A}$ & $47.50 \mathrm{~A}$ & $13.00 \mathrm{~A}$ & $7.6 \mathrm{~A}$ & 0.15 \\
Semisolid & $516 \mathrm{~B}$ & $6.88 \mathrm{~B}$ & $6.88 \mathrm{~B}$ & $5.2 \mathrm{~B}$ & 0.18 \\
\hline \multicolumn{5}{r}{} \\
\hline
\end{tabular}
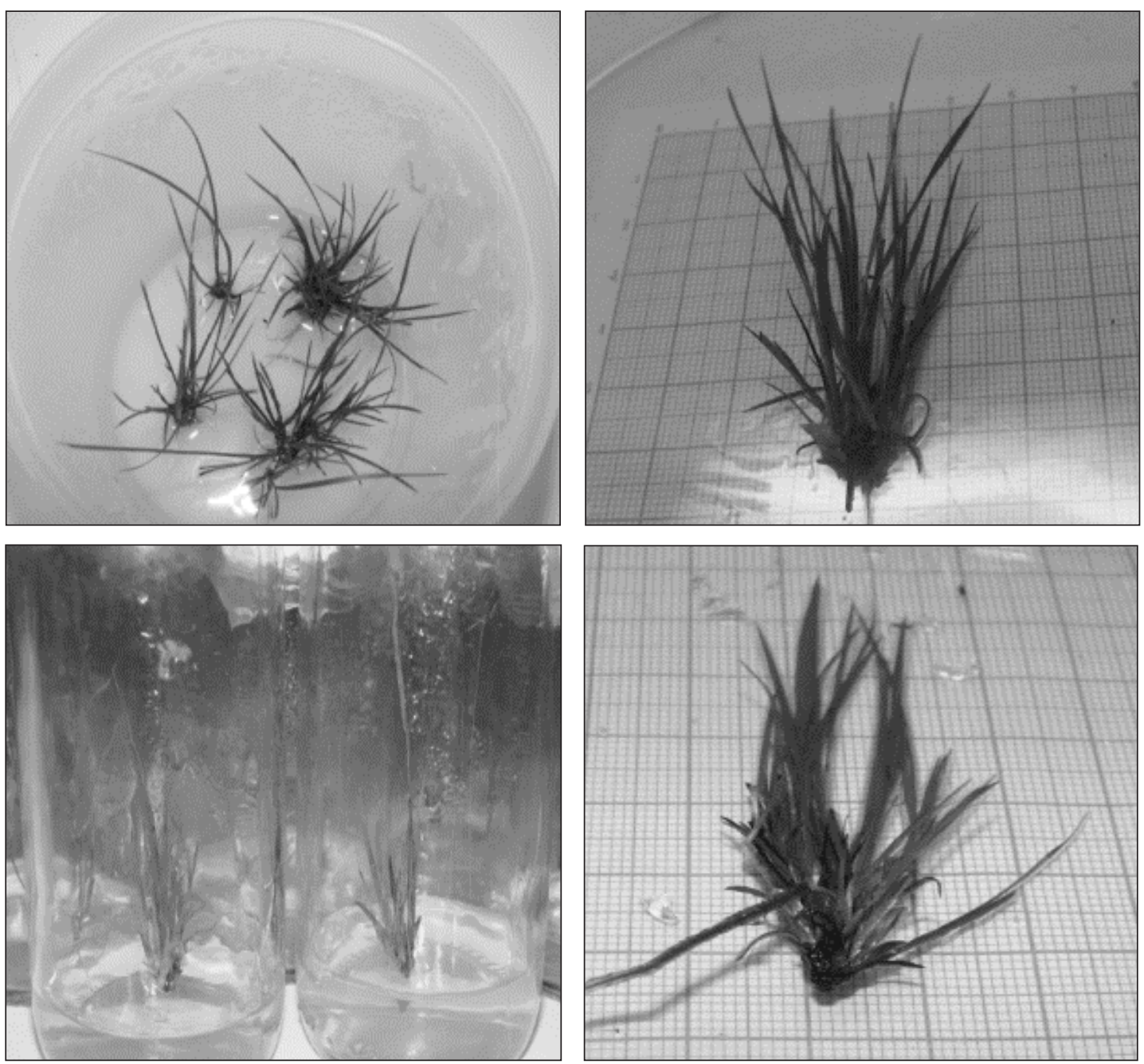

Figure 1. Upper row: Explants cultured in double phase medium, Lower row: Explants cultured in semisolid medium 
Culture media for in vitro tissue culture can be formulated as semisolid, liquid or double phase (liquid on top of semisolid) (Akhtar, 2013; Mehta et al., 2014; Litwińczuk, 2013). Semisolid media favor explant stability and allow to expand the time for subculture because slow nutrient and water release to the tissues; in contrast, they are usually more expensive because of gelling agents costs and nutrient absorption by tissues is slower; in contrast, liquid media are less expensive for absence of gelling agents, nutrient and plant regulators absorption by explants is faster, especially in cell suspension systems; (El-Hawaz et al., 2015; Perera et al., 2015). For liquid cultured tissues subcultures are more frequent because of nutrient depletion, tissue vitrification and phenol leakage in the medium that negatively affects growth and survival (Dong et al., 2016; Jones and Saxena, 2013). Double phase medium formulation combines the benefits of semisolid and liquid media: explant stability is provided by semisolid phase; rapid nutrient uptake is favored by liquid phase, the subcultures are eliminated by periodical addition of liquid medium which reduces cost from gelling agents, labor and support elements such as sealing material (Litwińczuk, 2013; López, 2013).

In semisolid medium system, subculture of plant tissue to fresh medium is necessary in order to provide constant adequate nutrient levels, to avoid tissue decay and to maintain high multiplication rates. During subculture, stems and leaves are cut back to maintain the shoot/container size ratio accordingly; additionally, shoot clusters are separated to scale up propagule number to keep high multiplication rates. The data collected in this research showed that cultures grown continuously with no transfers to fresh medium and absence of shoot cutting resulted in shoots $>40 \%$ larger than those sequentially severed, separated and transferred to fresh medium periodically during the 120 days of the research; this may indicate that subculture induces some stress levels by structure severing and high nutrient saturation on fresh medium that negatively affect shoot growth (Shin et al., 2013). Plant size is especially important for plant survival during transfer to ex vitro conditions; in vitro propagated plants grow under very low light intensities $\left(<60 \mu \mathrm{mol} \mathrm{m}{ }^{-2}\right.$ $\mathrm{s}^{-1}$ ) that prevents photosynthesis activation and therefore, energetic compound supply, usually sucrose, in needed, creating a heterotrophic (photomixotrophic) model for in vitro plant growth and development (Kapchina-Toteva et al., 2014; Nunes et al., 2016; Chavan et al., 2014). Because of this external energetic support, when transferred to ex vitro conditions, plants must have plenty of carbohydrate reserves in organs, such as leaves and stems, that serve as "life boat" effect before newly photosynthetic active leaves are formed. Therefore, micropropagated plants with larger organs will store more nutritional reserves and will have more opportunities to successfully withstand adaptation when transferring to natural environment (Kane, 1996; Resende et al., 2016; Zakavi et al., 2016).

Plants cultured in both systems had a complete survival percentage (100\%) seven weeks after transfer to ex vitro conditions; however, plants cultured in larger containers/double phase/ no transfer were in average larger $(13 \mathrm{~cm})$ than those cultured in semisolid media with monthly transfers to fresh medium $(5 \mathrm{~cm})$ (Figure 2); difference that may be the result of the higher reserve accumulation and rapid allocation for new organ formation in the first; however, more studies are recommended to deep into this topic.

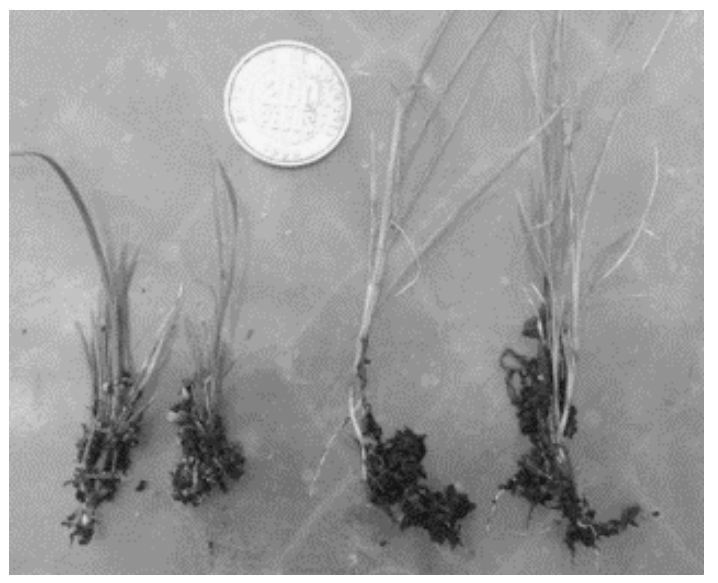

Figure 2. Ex vitro acclimatized plants from semisolid (left) and double phase (right) multiplication media, respectively. 


\section{CONCLUSSION}

Thepresentstudyhas shown thatmicropropagation of arrow cane shoots using double phase medium resulted in higher multiplication rates that may decrease micropropagated plant costs at least $20 \%$ compared to those micropropagated using semisolid medium system. Likewise, double phase cultured shoots were $40 \%$ larger which may have a beneficial impact on plant adaptation to ex vitro and growth when transferred to field conditions.

Conflict of interest: The authors declare that there is no conflict of interest.

\section{BIBLIOGRAPHIC REFERENCES}

Akhtar, N. 2013. Somatic embryogenesis for efficient micropropagation of guava (Psidium guajava L.). Methods in Molecular Biology. 11013: 161177. doi: 10.1007/978-1-62703-074-8_12.

Aramendiz, H., Espitia, M. \& Robles, J. (2005). Colección, conservación, caracterización morfoagronómica y producción de semilla de caña flecha (Gynerium sagittatum Aubl.) del Caribe Colombiano. CIUC, Universidad de Córdoba, Montería. Recuperada de https:// es.scribd.com/document/213150582/ Informe-Gynerium-Sagittatum-Aubl.

Couselo, J., Varela, P. \& Rey, M. (2006). Effect of benzyladenine concentration and doubléphase culture sistema on in vitro multiplication of adult Albariño plants. American Journal of Enology and Viticulture. 57(1):109-112.

Chavan, J., Nalawade, A., Gaikwad, N., Gurav, R., Dixit, G. \& Yadav, S. (2014). An efficient in vitro regeneration of Ceropegia noorjahaniae: an endemic and critically endangered medicinal herb of the Western Ghats. Physiol Mol Biol Plants. 20(3): 405-410. doi:10.1007/s12298014-0236-4.

DANE - Departamento Administrativo Nacional de Estadísticas. (2005). Censo General 2005. Recuperada de http://www.dane.gov.co/ censo/files/libroCenso2005nacional.pdf.
Dong, Ys., Fu, Ch., Su, P., Xu, Xp., Yuan, J., Wang, S., Zhang, M., Zhao, Cf. \& Yu, LJ. (2016). Mechanisms and effective control of physiological browning phenomena in plant cell cultures. Physiologia Plantarum. 156(1):13-28. doi: 10.1111/ ppl.12382.

El-Hawaz, R., Bridges, W. \& Adelberg, J. (2015). In Vitro Growth of Curcuma longa L. in Response to Five Mineral Elements and Plant Density in Fed-Batch Culture Systems. Plos One. 10(4). doi: https://doi.org/10.1371/journal. pone.0118912.

GRIN - Germplasm Resources Information Network. (2013). National Germplasm Resources Laboratory, Beltsville, Maryland. Recuperada de http://www.arsgrin.gov/cgibin/npgs/ html/tax_search.pl.

Jones, A. \& Saxena, P. (2013). Inhibition of phenylpropanoid biosynthesis in Artemisia annua L.: a novel approach to reduce oxidative browning in plant tissue culture. PLoS One. 8(10):1-13. doi. https://doi.org/10.1371/ journal.pone.0076802.

Kane, M. (1996). Propagation from preexisting meristems. En: Trigiano, R. N., \& Gray, D. J. (Eds.). Plant Tissue Culture Concepts and Laboratory Excercises. Second edition. Boca Ratón: CRC Press. 75-86.

Kalliola, R., Puhakka, M. \& Salo, J. (1992). Interspecific variation, and the distribution and ecology of Gynerium sagittatum (Poaceae) in the Western Amazon. Flora. 86(3-4): 153-16.

Kapchina-Toteva, V., Dimitrova, M., Stefanova, M., Koleva, D., Kostov, K., Yordanova, Zhp., Stefanov, D \& Zhiponova, Mk. (2014) Adaptive changes in photosynthetic performance and secondary metabolites during white dead nettle micropropagation. Journal of Plant Physiology. 171(15): 1344-1353. doi: 10.1016/j.jplph.2014.05.010.

López, C. (2013). Efecto del recipiente y medio de cultivo sobre la multiplicación in vitro de caña flecha (Gynerium sagitatum Aubl.). Montería: Universidad de Córdoba. 
López, C. (2016). Micropropagación de tres variadeades de Caña Flecha (Gynerium sagitatum Aubl.). Montería: Universidad de Córdoba.

Litwińczuk, W. (2013). Micropropagation of chokeberry by in vitro axillary shoot proliferation. Methods in Molecular Biology. 11013: 179-186. doi: 10.1007/978-1-62703-074-8_13.

Madera-Parra, C., Peña, M., Peña, E. \& Lens, P. (2015a). $\mathrm{Cr}(\mathrm{VI})$ and COD removal from landfill leachate by polyculture constructed wetland at a pilot scale. Environmental science and pollution research international. 22 (17): 12804-12815. doi: 10.1007/s11356-014-3623-z.

Madera-Parra,C.,Peña-Salamanca,E.,Peña, M., Rousseau, D. \& Lens, P. (2015b). Phytoremediation of Landfill Leachate with Colocasia esculenta, Gynerum sagittatum and Heliconia psittacorum in Constructed Wetlands. International Journal of Phytoremediation. 17(1): 16-24. doi: 10.1080/15226514.2013.828014.

Mehta, M., Ram, R. \& Bhattacharya, A. (2014). A simple and cost effective liquid culture system for the micropropagation of two commercially important apple rootstocks. Indian Journal of Experimental Biology. 52(7):748-754.

Murashige, T. \& Skoog, F. (1962). A revised medium for rapid growth and bioassay with tobacco tissue culture. Physiologia Plantarum. 15:473-497.

Nunes, S., Santos, C., Moutinho-Pereira, J., Correia, C., Oliveira, H., Ferreira De Oliveira, Jm., Pereira, Vt., Almeida, T., Marum, L. \& Dias, Mc. (2016). Physiological characterization and true-totypeness evaluation of in vitro and ex vitro seedlings of Pinus elliottii: A contribution to breeding programs. Plant Physiology and Biochemistry. 107: 222-227.

Pastrana, I. \& Suarez, I. (2009). Producción de plantas de caña flecha (Gynerium sagittatum) 'Criolla' a través de micropropagación. Temas Agrarios. 14(2): 2-18. doi: 10.21897/rta.v14i2.671.
Perera, D., Barnes, D., Baldwin, B. \& Reichert, N. (2015). Direct and indirect in vitro regeneration of Miscanthus $\mathrm{x}$ giganteus cultivar Freedom: effects of explant type and medium on regeneration efficiency. In Vitro Cellular \& Developmental Biology- Plant. 51(3): 294-302.

Resende, C., Braga, V., Pereira, P., Silva, C., Vale, V., Bianchetti, RE., Forzza, RC., Ribeiro, C. \& Peixoto, PH. (2016). Proline levels, oxidative metabolism and photosynthetic pigments during in vitro growth and acclimatization of Pitcairnia encholirioides L.B. Sm. (Bromeliaceae). Brazilian Journal of Biology. 76(1): 218-227. doi: 10.1590/15196984.19314.

Rivera, H., Suarez, I. \& Palacio, J. (2009). Análisis de la diversidad genética de caña flecha Gynerium sagittatum Aubl. utilizando la técnica de AFLP. Agricultura Técnica en México. 35(1): 81-87.

Scherwinski-Pereira, J., Araruna, E., Da Silva, T., Gomes, A., Maciel, S. \& Da Silva, F. (2012). Double-phase culture system for large-scale production of pineapple. Plant Cell Tissue and Organ Culture. 109: 263-269.

Sinhg, S., Sinhg, R., Kalia, S., Dallal, S., Dhawan, A. \& Kalia, R. (2013). Limitations, progress and prospects of application of biotechnological tools in improvement of bamboo-a plant with extraordinary qualities. Physiology and Molecular Biology - Plants. 19(1): 21-4. doi:10.1007/s12298-012-0147-1.

Shin K-S., Park S-Y. \& Paek K-Y. (2013). Sugar metabolism, photosynthesis, and growth of in vitro plantlets of Doritaenopsis under controlled microenvironmental conditions. In Vitro Cellular \& Developmental Biology - Plant. 49(4): 445-454.

Singh, P., Guleri, R. \& Pati, Pk. (2016). In Vitro Propagation of Withania somnifera (L.) Dunal. Methods in Molecular Biology. 1391:201-213. 2016. doi: 10.1007/978-1-4939-3332-7_14.

Suarez, I., Aramendiz, H. \& Pastrana, I. (2009). Micropropagación de Caña Flecha (Gynerium 
sagittatum Aubl.). Revista Facultad Nacional de Agronomía. 62(2): 5135- 5143. doi: 10.14198/ cdbio.2011.37.01.

Suarez, I., Pastrana, I. \& Rivera, H. (2013). Biotecnología Aplicada a la Caña Flecha (Gynerium sagitatum Aubl.). Montería, Colombia: Fondo Editorial Universidad de Córdoba. 70p.

Suarez, I., López, 0. \& López, C. (2017). Formación in vitro de rizomas en caña flecha (Gynerium sagitatum Aubl.) y recuperación de plantas. Revista Temas Agrarios 22(1). 11-20. doi:10.21897/rta.v22i1.911.

Shin, K-S., Park, S-Y \& Paek, K-Y. (2013). Sugar metabolism, photosynthesis, and growth of in vitro plantlets of Doritaenopsis under controlled microenvironmental conditions. In Vitro Cellular \& Developmental Biology - Plant. 49(4): 445-454. doi:10.1007/s11627-0139524-x.

Shinde, S., Sebastian, J., Jain, J., Hanamanthagouda, M. \& Murthy, H. (2016). Efficient in vitro propagation of Artemisia nilagirica var. nilagirica (Indian wormwood) and assessment of genetic fidelity of micropropagated plants. Physiology and Molecular Biology of Plants. 22(4): 595-603. doi: 10.1007/s12298-016-0379-6.

Scherwinski-Pereira, J., Araruna, E., Da Silva, T., Gomes, A., Maciel, S. \& Da Silva, F. (2012). Double-phase culture system for large scale production of pineapple. Plant Cell Tissue and Organ Culture. 109(2): 263-269. doi: 10.1007/s11240-0110091-8.

Waikhom, S. \& Louis, B. (2014). An effective protocol for micropropagation of edible bamboo. The Scientific World. Recuperada de https://www.hindawi.com/journals / tswj/2014/345794/. doi. http://dx.doi. org/10.1155/2014/345794.

Zakavi, M., Askari, H. \& Irvani, N. (2016). Optimizing micropropagation of drought resistant Pyrus boissieriana Buhse. Physiol Mol Biol Plants. 22(4): 583-593. doi: 10.1007/s12298-0160387-6. 